廃棄プラスチック樹脂のサーマルリサイクルに関する研究*

(バーナ内部の燃焼ガスと PET 粉末の流動および 飛しょう PET 粒子の形状と直径変化の画像計測)

\author{
山北龍 児*1, 佐 藤毅*2 \\ 石 野 洋二郎*3, 大 岩 紀 生*3
}

\title{
An Investigation on Thermal Recycling of Recycled Plastic Resin \\ (PIV/PTV Measurements of Flow Characteristics and Appearances of Flying PET-Particles in the Improved Industrial Burner)
}

Ryuji YAMAKITA, Tsuyoshi SATO,

Yojiro ISHINO and Norio OHIWA*4

${ }^{* 4}$ Graduate School of Engineering, Nagoya Institute of Technology,

Gokiso-cho, Showa-ku, Nagoya-shi, Aichi, 466-8555 Japan

The possibility and applicability of thermal recycling of recycled PET-resin for the industrial burner systems have been investigated by supplying PET-resin powder as an auxiliary fuel to the improved commercial LPG-fuelled ceramic burner. The results showed that a large amount of PETpowder up to $80 \%$ is exhausted without burn-up in the open atmospheric operation, whereas it is perfectly consumed in the in-furnace operation. In this paper, in order to obtain key reasons why a large amount of PET-powder is exhausted without burn-up in the cold open atmospheric operation of the industrial burner and to reduce the amount of the unburnt PET-powder, the interrelation between the flow patterns and the dispersion profiles of PET-powder in and downstream of the burner is examined by employing the PIV/PTV system. Appearances and diameters of PET particles flying through the combustion zone downstream the stabilizer are also observed using the proposed technique. According to the results, three factors having great influences on the unburnt rate of PET-powder are found.

Key Words : Heterogeneous Combustion, Thermal Recycling, Waste PET-Resin Powder, Unburnt Rate, PIV/PTV Measurements

\section{1. 緒}

容器リサイクル法が施行されてから, 膨大な量の廃 棄プラスチック樹脂が回収されているが，その大部分 が利用されずに蓄積され, 今なお環境問題の一つとな っている. 廃棄プラスチック樹脂は高純度の炭化水素 化合物から構成されており, 燃料としての再利用(サ ーマルリサイクル)が可能であり，それに関してさま ざまな研究が行われてきた(1) (4). また, 手法そのもの が最終処理に相当するという特徵をもち, 商・工業用 燃料に利用した場合には, 化石燃料使用量の節減効果 も有し，エネルギー環境保全につながると考えられ る.

そこで, 本研究ではこれまで, 廃棄プラスチック樹 脂の一種である廃棄 PET (polythylene terephthalate) 樹脂粉末(PET 粉末と略記)を助燃料とするた め, まずプロパンを燃料とする市販の窯業用バーナの

\footnotetext{
* 原稿受付 2005 年 3 月 29 日.

*1 正員, 名古屋工業大学大学院工学研究科( - 466-8555 名古 屋市昭和区御器所町).

*2 (株) トヨ夕自動車（471-8571 豊田市卜ヨ夕町 1).

*3 正員, 名古屋工業大学大学院工学研究科.

E-mail : oiwa.norio@nitech.ac.jp
}

燃焼領域に, PET 粉末を溶着せずに直接供給できる ように改良を加えた。そしてこの改良バーナを用い て, 窯業炉内における燃焼特性 ${ }^{(5)}$ (8) を把握した。 た一方で，環状バーナを用いた燃焼特性の把握 ${ }^{(9)}$ ，単 一微粒子の急速加熱過程の可視化実験(10)(11) と球対称 一次元解析 ${ }^{(12)}$ をすでに実施してきた。

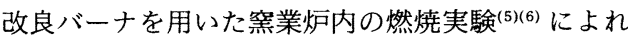
ば, (1)供給したPET 樹脂粉末はすべて蒸発・燃焼し て消費されること，(2)炉内に焼成に必要な高温で均一 な空間温度場が形成されること, (3)焼成の最終工程で 要求される還元䨌囲気の制御が可能なこと, (4) PET 粉末供給時にも焼成品の白色度が維持されること，な どの特性が得られ, 窯業用助燃料としての可能性が示 された。しかし，低温の大気開放条件下で改良バーナ を作動させた場合には, PET 粉末の平均粒径に依存 して, 供給量の $80 \%$ を超える粉末が末燃のまま排出さ れた.この主原因として, バーナ出口下流での周囲空 気の誘引による冷却が考えられるが, 廃棄プラスチッ ク樹脂の燃料としての効果的な再利用を図るために は，さらにバーナ内部から出口下流域のできるだけ広 い範囲におけるプロパン火炎の燃焼ガスと PET 粉末 の流動状況を把握し, 未燃率増大に関係する諸要因を 
探る必要がある。

そこで本論文では，プロパン火炎のみのバーナ内部 の燃焼がス流動場のPIV 計測, ならびにPET粉末供 給時の燃焼ガスとPET 粒子の流動状沅および PET 粒子の形状変化の PTV 計測を行った。得られた結果 と末燃率の测定結果との関係から未燃の要因を策定 し, PET 粉末燃焼用のバーナに不可欠な要件を検討 した。なお，PET 粉末の供給にあたつては，粒径分布 との対応関係を明確にするため, 粉末を分級して大中 小の 3 種類に分割し，火炎概形と未燃率の測定を行っ た。

\section{2. 実験装置および方法}

$2 \cdot 1$ 実験装置の構成 実験装置は, PET 粉末燃 焼用改良バーナ，プロパン供給系，プロパン用空気供 給系, PET粉末供給系，抢よび各種計測装置から成 る(6).用いたプロパンは市販のLPGで, 純度は $96.4 \%$ である.

2.2 PET 粉末燃焼用改良バーナ 図1(a)に用 いた改良バーナの直接写真を, 図 $1(\mathrm{~b})$ にPET 粉末 供給用に改良されたバーナ基部の構造と寸法を示す。 バーナ内の火炎の直接観察が可能なようにセラミック ス製のバーナタイルを石英ガラス管(内径 $28 \mathrm{~mm}$ ，長 さ $220 \mathrm{~mm}$ )に置さ換えた点，および PET 粉末を直接 燃焼領域に導入するための搬送管(内径 $4 \mathrm{~mm}$, 外径 5 $\mathrm{mm}$, 長さ $202 \mathrm{~mm}$ ) をバーナ軸に沿って設置した点が 市販の窯業用バーナからの改良点である。

プロパンと空気は所定の流量でバーナ上流部で半径 方向内向きに流入・混合し，保炎器下流に予混合火炎 を形成させる。PET 粉末は，搬送用空気とともにバ 一十中心部の供給管を通って保炎器出口直後の中心軸

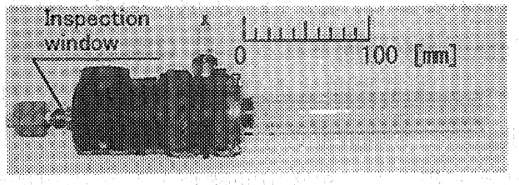

(a) Direct photograph of the burner

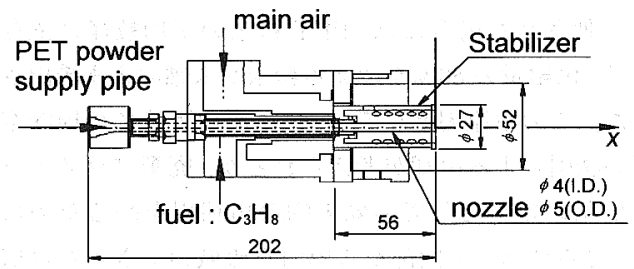

(b) Detailed construction and dimensions of the burner

Fig. 1 The improved twin-fueled burner used
近傍のプロパン火炎領域に供給され，その下流に輝炎

のPET 粉末火炎を形成させる.

粉末を構成する粒子の粒径分布の影響を明確にする ため，質量メディアン直径 $d_{m}=176.4 \mu \mathrm{m}$ の粉末を\# 80 および柆50のふるいを用いて大： $d>180 \mu \mathrm{m}$, 中: $100 \mu \mathrm{m}<d \leq 180 \mu \mathrm{m}$, 小: $d \leq 100 \mu \mathrm{m} の 3$ 種に分 級した。なお, PET 粉末の低位発醇量は $\Delta H_{c}=21.8$ $\mathrm{MJ} / \mathrm{kg}^{(1)}$, 密度は $\rho_{\mathrm{PET}}=1.38 \times 10^{3} \mathrm{~kg} / \mathrm{m}^{3(13)}$ である。

$2 \cdot 3$ 未燃 PET 粒子捕集装置大気開放燃焼実 験で用いた捕集装置の概略を図 2 に示す.バーナ出口 から $400 \mathrm{~mm}$ の位置に重直に衝突板を置きここの板の 上部加ら水道水を流して水膜を形成させ, 燃焼がスを 衝突させて未燃PET 粒子を受け止めてフィルタで捕 集する. 捕集された未燃 PET 粒子質量 $m_{\mathrm{C}, \mathrm{PET}}$ と供給

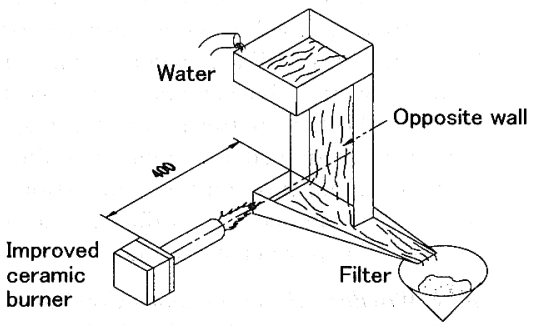

Fig. 2 Schematic diagram of the water curtain method; collection of unburned plastic-particles

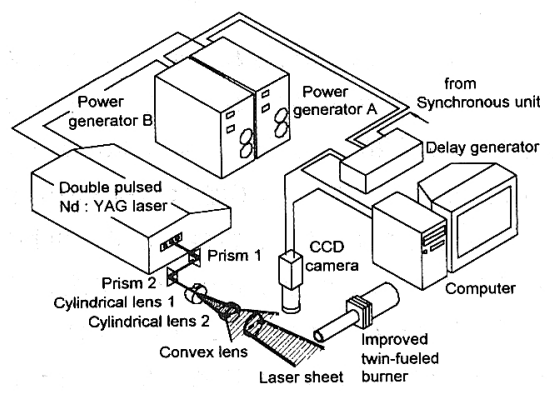

(a) System for PIV/PTV measurements

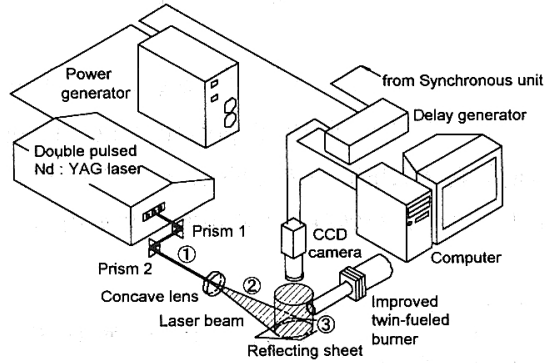

(b) System for magnifying particle imaging

Fig. 3 Schematic diagrams of two optical systems 


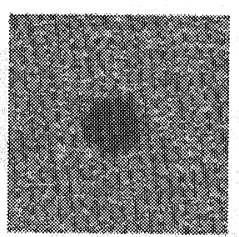

(a) Photograph

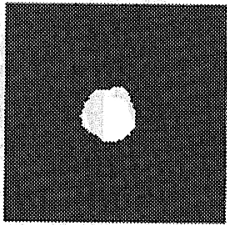

(b) Segmentation
Fig. 4 Direct and processed photographs of a PETparticle

PET 粉末質量 $m_{\mathrm{PET}}$ の比を用いて, 未燃率を $M_{\mathrm{PET}}=$ $m_{\mathrm{C}, \mathrm{PET}} / m_{\mathrm{PET}}$ と定義した. なお, ガラス管への溶着は ほとんど確認されなかった。

2・4 PIV/PTV 計測装置 プロパン火炎の然焼 流動場計測に用いたPIV/PTV 計測装置の系統図を 図 3(a)に示す. 本実験の改良バーナによって形成さ 扎るPET 粉末火炎は輝炎の形態を取り, PET 粒子は 火炎中を燃焼ガスとともに高速度で飛しょうする。そ のため, パルス発光時閒が短く出力の大きいダブルパ ルス Nd：YAGレーザ(Continuum 製, CLP 10 PIV, 発振波長 $532 \mathrm{~nm}$, 最大出力 $220 \mathrm{~mJ} /$ pulse, パルス幅 5 ns）を光源として採用し，撮影には CCDカメラを用い た.レーザ光は光学系によって厚さ $0.3 \mathrm{~mm}$, 幅 50 $\mathrm{mm}$ のシート光として測定部に入る.レーザ光のト リガとカメラシャッタの同期には, 遅延装置を用い た。また, 火炎の自発光の写り込みを避けるため, 中 心波長 $532 \mathrm{~nm}$, 透過率 $80.0 \%$ 有する干涉フィルタ を装着させた。

なお, PIV 計測時のトレーサ粒子には市販の歯科用 焼石こう(粒子径約 $20 \mu \mathrm{m}$ ) を, PTV 計測時のトレー サ粒子には粒子径 $100<d \leq 180 \mu \mathrm{m}$ に分級された PET 粉末を用いた。また, 1 断面の速度分布を得るの に用いたPIV デー夕数は 60 個, 1 断面の粒子分布招 よび粒子存在確率の算出に用いた PTV 計測時の粒子 数は約 3000 個である.

$2 \cdot 5$ 飛しょう PET 粒子形状の拡大観察 本実 験では, 既存の PIV/PTV システムに工夫を加え, 高 速で飛しょう中のPET 粒子形状の瞬間拡大観察を可 能にした。図 3(b)に, PIV/PTV 計測に用いたダブ ルパルスレーザの一方を停止させ，もう一方のパルス 光のみを利用した拡大撮影装置の系統図を示す.第 1 および第 2 プリズムを用いて光軸を調節されたパルス

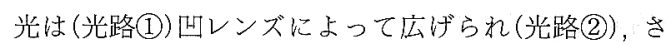
らに測定断面下部で反射シート(白紙)によって垂直上 方に曲げられて測定断面を通過し(光路(3))，粒子を照 射する. $5 \mathrm{~ns} と い う$ 短いパルス幅を有するレーザ光で

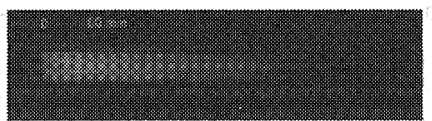

(a) Without PET powder supply

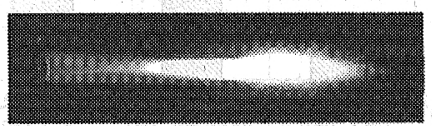

(b) $\quad d \leq 100 \mu \mathrm{m}$

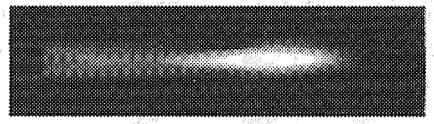

(c) $100 \mu \mathrm{m}<d \leq 180 \mu \mathrm{m}$

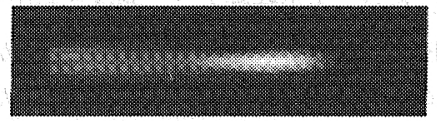

(d) $d>180 \mu \mathrm{m}$

Fig. 5 Variation of flame appearances with sieved PET-powder $; \phi_{m}=0.8, \quad H_{m}=11.6 \mathrm{~kW}, m_{\mathrm{PET}}=$ $9.6 \mathrm{~g} / \mathrm{min}$

照射された飛しょう中のPET粒子は, 接写レンズ (Ken 製，40 mm) を介して比較的シャープな画像とし て記録される。なお, 予備実験の粒子画像の検討結果 によれば,この光学系の焦点深度は土0.5 mm と見積 もられている。

図 4(a)に, 256 階調で撮影された粒子画像の一例 を示す。また, この画像の明暗を反転させて二值化処 理を施した画像を図 4(b)に示す。应 4(b) を見ると, 粒子の影の翰郭が正確に表示されていることが知れ る.そこで，この白い領域のピクセル数から粒子の投 影断面積を求め，それに等価な投影断面積を有する球 状粒子を想定し，その粒子径の下流方向の変化を把握 した.

$2 \cdot 6$ 実験手順および方法 実験に際しては，ま ずプロパン火炎を形成させ，それに 3 種類に分級され たPET 粉末を供給して燃焼状態の観察と未燃粒子量 の測定を行う。この場合, 5 min にわたる 2 回の測定 を行い, それらの平均值を末燃PET 粉末量とした。 続いて, プロパン火炎の燃焼流動場の PIV 計測, なら びに PET 粉末供給時のPET 粒子速度, 粒子の存在 確率の算出, および飛しょう中の粒子形状の拡大観察 を行う. 最後に, 拡大粒子画像を解析することにより, 下流方向への粒子径の変化を把握する。

なお，用いた石英分ラス管は $14 \mathrm{~mm} の$ 半径に対し て $2 \mathrm{~mm}$ の肉厚を有するので, ガラス管内の壁面近傍 に㧍ける粒子画像への影響が予想される。しかし，本 


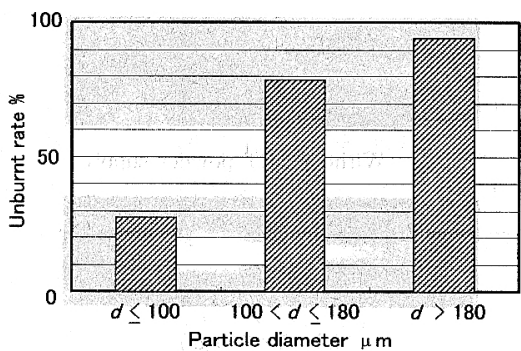

Fig. 6 Variation of unburnt PET-particle rate with sieved PET powder ; $H_{m}=11.6 \mathrm{~kW}, m_{\mathrm{PET}}=9.6$ $\mathrm{g} / \mathrm{min}$

実験で用いたバーナの特性から，ガラス管内では供給 されたPET 粉末の中心軸まわりへの集中が激しく， 壁面近傍の粓子存在確率が小さいてと，したがって， ガラス管内の粒子挙動の平均的考察に対する影響は小 さいと考えられること,および中心軸に沿う平均粒子 速度を除いて定量化を行っていないこと, などの理由 から，本論文ではガラス管内部の屈折率の影響を考慮 していない.

\section{3. 実験結果および考察}

$3 \cdot 1$ 改良形窯業用バーナの開放燃焼特性 本実 験では，はじめに分級された 3 種類の粉末粒径 $d$ をパ ラメータとし, 各粒径条件における火炎挙動および末 燃率の把握を行った。PET 粉末を供給する前のプロ パン火炎の設定条件に関しては, 当量比を $\phi_{m}=0.8$ に, 発熱速度を $H_{m}=11.6 \mathrm{~kW}$ に固定した。そして, その燃焼場に PET粉末を $m_{\mathrm{PET}}=9.6 \mathrm{~g} / \mathrm{min}$ 供給し た.な招, PET粉末の発熱速度は $H_{\mathrm{PET}}=3.5 \mathrm{~kW}$ に 相当要る。

$3 \cdot 1 \cdot 1$ 粒子径が火炎挙動に及ぼす影響 図 5 に, 火炎の直接写真を示す。図 5(a) はPET 粉末を供給 する前のプロパン火炎を，図5(b)，(c) 拈よび図 5 (d) はそれぞれ小: $d \leq 100 \mu \mathrm{m}$, 中： $100 \mu \mathrm{m}<d \leq$ $180 \mu \mathrm{m}$, 大： $d>180 \mu \mathrm{m}$ に分級されたPET 粉末を供 給した場合の火炎を表す。な挔, PET粉末の有無に よる火炎形状の変化は文献 (6)に記されているので, ここでは省略する。

図 5 によれば，分級された粒子径が小さい活ど火炎 は太くから長くなり，輝炎の発光も強くなっている. また，輝炎の発光開始位置もより上流任位置する。微 細な粒子は粗大な粒子に比べて早期に融解・蒸発・着 火すると考えられるので, 同一の滞在時間および PET 粉末供給量の条件下では，微細な粒子を多く含 む粉末活ど钲発量も多くなり,PET 蒸気の活発な拡

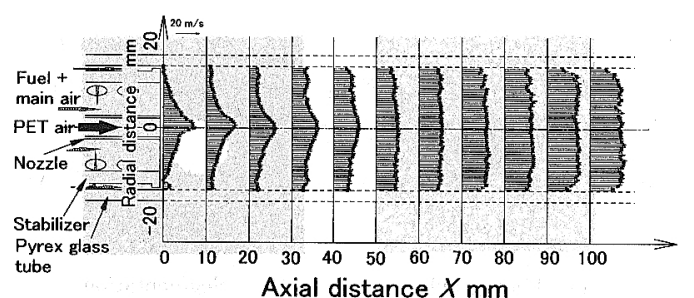

Fig. 7 Mean velocity profiles across the sections with out PET-powder supply $\left(\phi_{m}=0.8\right)$

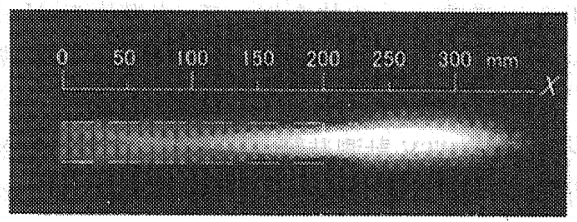

Fig. 8 Appearances of the PET-powder flame $\left(\phi_{m}=\right.$ $0.8, m_{\mathrm{PET}}=9.6 \mathrm{~g} / \mathrm{min}$ )

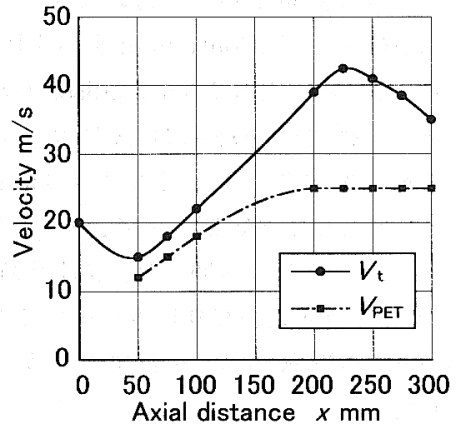

Fig. 9 Velocity variations along the axis

散燃焼がそれに続く：その結果，図5のような顕著な 相違が現れると考えられる。

$3 \cdot 1 \cdot 2$ 水膜法による未燃率の定量的検討 図 6 に未燃率の測定結果を示京。左から順に，小： $d \leq 100$ $\mu \mathrm{m}$, 中 : $100 \mu \mathrm{m}<d \leq 180 \mu \mathrm{m}$, 大: $d>180 \mu \mathrm{m}$ に分 級したPET 粉末を用いた場合である。図 6 によれば,

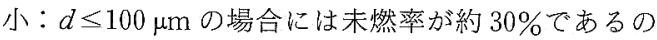
飞対して, 大： $d>180 \mu \mathrm{m}$ の場合には 90\%を超えて おり，ほとんど蒸発・燃焼せずに大気中に飛散してい るのがわかる。中： $100 \mu \mathrm{m}<d \leq 180 \mu \mathrm{m}$ の場合には， この粉末中に $180 \mu \mathrm{m}$ に近い直径の粒子を多く含んで いるため,大： $d>180 \mu \mathrm{m}$ の場合と同様に高い未燃率 (約 80\%) を示している.

この末燃率の測定結果は火炎形状に基づく予測結果 とよく符号しているので, 定性的には, 火炎発光強度 が弱く火炎長が短い場合には, PET 粉末の多くは蒸 

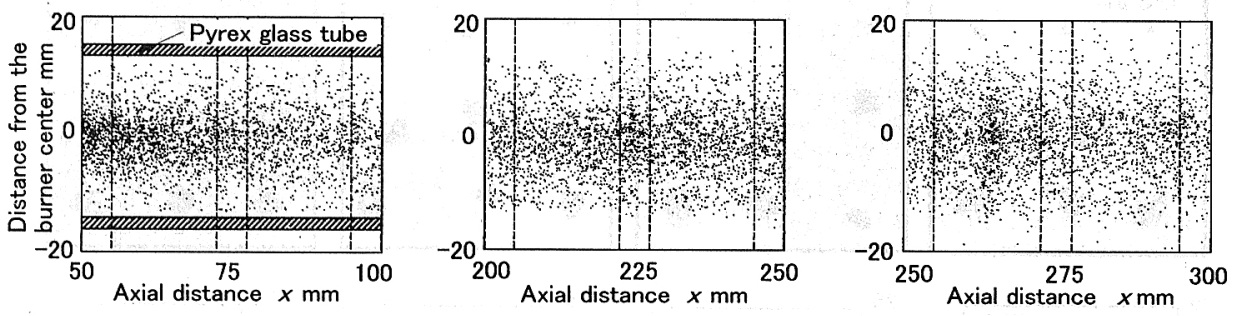

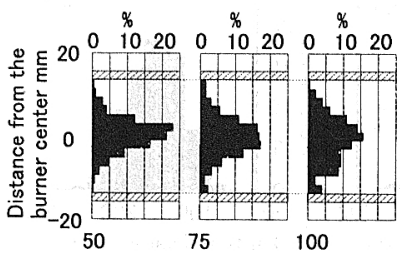

(a) $x=50 \sim 100 \mathrm{~mm}$

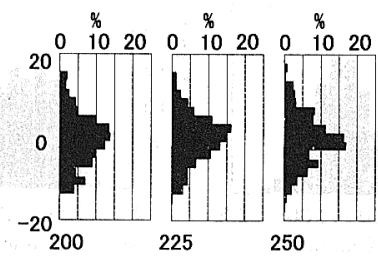

(b) $x=200 \sim 250 \mathrm{~mm}$

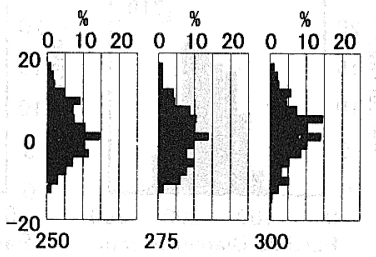

(c) $x=250 \sim 300 \mathrm{~mm}$

Fig. 10 Variations of distributions and histograms of PET-particles

発・燃焼せずに大気中に飛散していることがわかる. $3 \cdot 2$ 燃え残りの諸要因の検討 本節では, $3 \cdot 1$ 節 の結果を受けて燃え残りの諸要因を検討する。設定条 件はプロパン火炎の当量比と発熱速度を $\phi_{m}=0.8$ と $H_{m}=11.6 \mathrm{~kW}$ とし, $100 \mu \mathrm{m}<d \leq 180 \mu \mathrm{m}$ に分級され た PET 粉末の供給量を $m_{\mathrm{PET}}=9.6 \mathrm{~g} / \mathrm{min}$ とした.

$3 \cdot 2 \cdot 1$ プロパン火炎中の軸方向速度の断面分布

図 7 亿, ガラス管内のプロパン火炎の主燃燒領域に おける 11 断面の軸方向平均速度の断面分布を示す. 横軸は保炎器出口からの距離 $x$ を表す。図 7 に上れ ば, 下流方向に進むに従い平均化されていくと同時に 加速されていることがわかる. 加速流中に扔ける 2 流 体は混合しにくい性質があるので(14)(15), PET 粒子は 分散されにくい条件下に供給されていることがわかる. $3 \cdot 2 \cdot 2$ PET 粒子速度および存在確率の断面分布 図 8 に, $100 \mu \mathrm{m}<d \leq 180 \mu \mathrm{m}$ の PET 粉末を供給し た場合の火炎の直接写真を改めて示す. 図 8 中には, PET 粉末燃焼挙動と PIV およびPTV の計測位置と の関係がわかるよう軸方向距離 $x$ が併記されている. 図 9 にその火炎の中心軸上に打ける燃焼ガス速度 $V_{t}$ およびPET 粒子速度 $V_{\mathrm{PET}}$ の推移を示す. 燃焼ガス 速度および PET 粒子速度の測定に関しては, それぞ れ図 9 中に記された印(9点)および回印(8 点)の中 心軸上の位置で行った。

図 8 を見ると, $x \geq 100 \mathrm{~mm}$ の領域に輝炎が発生し, ガラス管出口下流の $x=200 \sim 300 \mathrm{~mm}$ の領域で最も 発光が著しい.したがって,この領域では融解・蒸 発・燃焼に伴うPET 粒子径の顕著な減少が予想され る.

一方図 9 によれば, $x \leq 100 \mathrm{~mm}$ の上流域では,
PET 粒子と燃焼ガスはほぼ等しい軸方向速度と下流 方向への速度増加の傾向を示している.しかし $x \geq$ $150 \mathrm{~mm}$ の下流域では, 燃焼ガス速度が $x=225 \mathrm{~mm}$ 付近で最大值 $V_{t}=42.5 \mathrm{~m} / \mathrm{s}$ に達してから減速してい るのに対して, PET 粒子速度は $V_{\mathrm{PET}}=25 \mathrm{~m} / \mathrm{s}$ とほほ 一定値を示している。このような両者の速度挙動の差 が生じる要因として, 燃焼ガス流速の PIV 計測沉用 いたトレーサ粒子と PET 粒子の粒径と質量の差扔よ び慣性力によるPET 粒子の加速遅れなどが挙げられ る.

なお，図 9 の結果に基づいて， $x=0 〜 300 \mathrm{~mm}$ の火 炎領域沉おける PET 粒子の滞在時間を概算すると約 $15 \mathrm{~ms}$ となった。この滞在時間は, 単一球形粒子の急 速加熱実験の球対称一次元解析結果 ${ }^{(12)}$ に抢いて得ら れた粒径 $150 \mu \mathrm{m}$ の粒子の寿命に比して短い.このよ うな高温領域における滞在時間が不十分である PET 粉末の燃焼条件も, 未燃率增大の要因の一つとなるこ とが知れる。

次に, PTV 画像における粒子座標を統計的に処理 して得られた粒子の空間分布図と存在確率のヒストグ ラムを，それぞれ図100上側と下側に示す。上図に 関しては, ガラス管内の $x=50 \sim 100 \mathrm{~mm}$ の領域と, バーナ出口下流の $x=200 \sim 300 \mathrm{~mm}$ の中心軸を通る 横断面に扔いて計測した。 また下図のヒストグラム は，上図中に引かれた $5 \mathrm{~mm}$ 間隔の 2 本の破線氾囲ま れた領域内に存在する粒子群に基づいて作成されてい る.

図 10（a）によれば, $x=50 \mathrm{~mm}$ 断面の中心軸付近に 偏って多く存在していた PET 粒子が, $50 \sim 100 \mathrm{~mm}$ の範囲ではがラス管内全体に分散していくようすが観 

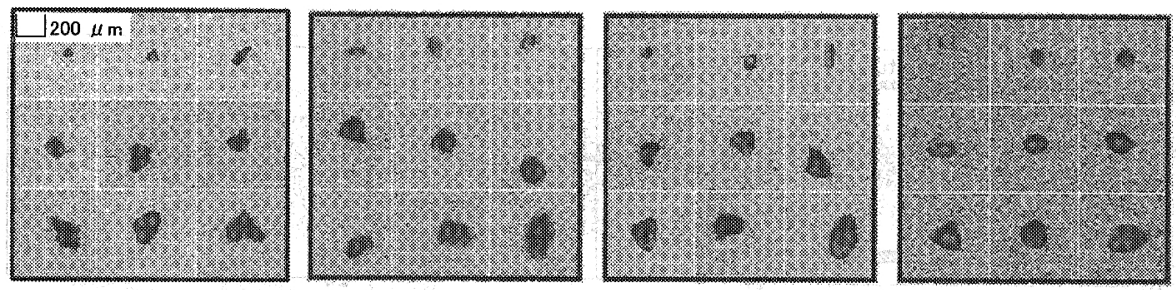

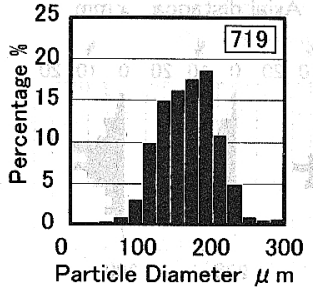

(a) cold flow $(x=50 \mathrm{~mm})$

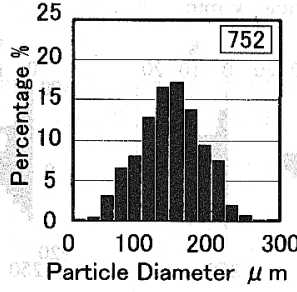

(b) $x=100 \mathrm{~mm}$

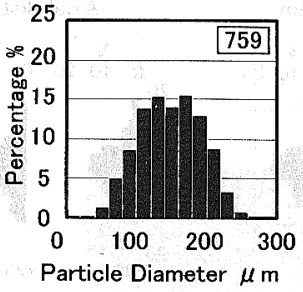

(c) $x=200 \mathrm{~mm}$

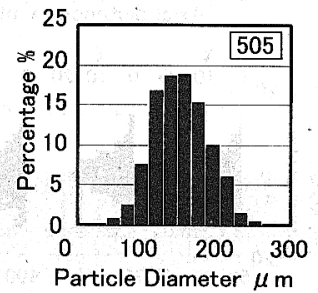

(d) $x=300 \mathrm{~mm}$

Fig. 11 Variations of direct photographs and histograms of PET-particles

察できる。しかし，それより下流の断面 [図 10(b)， (c)］ではわずかにPET 粒子の存在範囲が広がるも のの, 大部分の粒子が中心軸付近に存在していること が知れる。この原因の一つとして, 先に述べたがラス 管内での加速流の影響が考えられる。

以上の PIV/PTV 計測の結果から, 未燃率を大きく する要因として, 加速流の影響によりバーナ内抗い てPET 粒子が効果的に分散されていなかったこと， PET 粒子が中心軸付近に多く偏って存在しているた 個及の粒子への熱伝達が阻害されて有効に熱が利用 されていなかったこと，および高温領域饮おける十分 な滞在時間が得られていなかったことの 3 点が考光ら れる。これにより，未燃率低隇のための基本的なバー ナ設計方針が得られたことになる.

$3 \cdot 2 \cdot 3$ 飛しょう PET 粒子の形状と粒径変化

図11に，いくつ加の代表的な計測断面に抒ける PET 粒子写真扔よび粒子径計測結果から得られた七 ストグラムを示す。図11(a) 証燃焼時の $x=50$ mm 断面, 図11(b)，(c)および図11(d)はそれぞ れ燃焼時に扔ける $x=100,200,300 \mathrm{~mm}$ の断面の測 定結果である。下側の図中の右上の数字は計測に用い たデー夕数を表す。な掠, 図11 に示した粒子写真法 互い対応するものではなく，得られた画像から任意 に抽出されたものである。

上図加ら，まず非燃燒時に撮影された粒子の概形は スパイラルミルで粉砕されたままの角張った不規則な 形を呈している。しかしいったん，高温燃焼時にさら されて融解過程を経ると,小さい粒子から次第比角が 丸くなり，中心部分が明るくなっていく。このような
概形の変化は下流ほど激しく，融解による形状変化と 光の透過性の増大が主要因となっていると考光られ る.

一方，図 11 下図のヒストグラムを見ると，測定断面 が下流側へ移動するのに従い，分布のピークが粒径の 小さい方向へ移行していく傾向が見られる。しかし， PET 粒子の平均粒径の大きい本論文の作動条件では 基本的に未燃率が高いため，ヒストグラムに現れる変 化は小さいと考えられる。

以上，レーザ光を背景光に用いることにより，高速 燃燒ガス中を飛しょうしている PET 粒子の詳細な形 状観察と粒子径計測が可能となり, 下流方向への PET 粒子の形状と粒径の変化を把握することができ た.

\section{4. 結言}

本論文では, PET 粉末燃焼用改良バーナが大気開 放燃焼させたときの未燃PET 粒子量を測定し, 粒子 径に伴う未燃率の変化を把握した。そして, その未燃 率を系統的に低隇させるために，燃え残りの諸要因を 検討した。得られた結果は以下のように要約される。

（1）PIV/PTV 計測結果から，末燃率を高くする 要因として, 加速流の影響によりバーナ内において PET 粒子が効果的に分散されていないこと, PET 粒 子が中心軸付近に多く存在して粒子個々への熱伝達が 悪く有效に熱が使われていないこと，十分な滞在時間 が得られていないことの 3 点が考えられる。

（2）ダブルパルスレーザの一方の光を背景光とし て利用することにより，燃焼領域を飛しょうしている 
粒子の詳細な形状の拡大観察を可能にした。また, 得 られた粒子写真に画像処理を施して粒子径計測を行う ことで, 下流方向への粒子径変化も明らかにした。

今後は, 得られた末燃率を増大させる諸要因を加味

しながら，良好な燃え切り特性を有する実用バーナの

開発を系統的に進めていく.

本研究の実施にあたり, 大学院前期課程一年生の加 藤雄貴君の多大な協力を得た.

\section{文献}

（1）既設発電ボイラーを対象とした廃プラスチック燃料化基 礎技術の調查研究報告書, (社) プラスチック処理促進協 会, (1993).

（2）プラスチックのサーマルリサイクル技術基礎デー夕集, (社) プラスチック処理促進協会, (1993).

(3) Williams, P. T. and Williams, E. A., J. Inst. Energy, (1998), 81-93.

(4) Zhao, B. and Bar-Ziv, E., Proc. Combust. Inst., 28 (2000), 2659-2666.

( 5 ) Ishino, Y., Yamakita, R., Kuroda, S., Kato, M., Yasuda, M. and Ohiwa, N., Proc. 6th ASME-JSME Thermal
Eng. Joint Conf., (2003-3), CD-ROM : Paper No. TED-AJ 03-181.

（6）山北龍児 - 石野洋二郎 - 大岩紀生，機論， 71-701， B (2005), 357-364.

（7）佐藤毅 - 山北龍児 - 石野洋二郎 - 黒田茂男 - 安田益雄 大岩紀生, 第 13 回環境工学総合シンポジウム講論集, No. 03-10 (2003), 326-329.

（8）石野洋二郎・黒田茂男・山北龍児・加藤正樹 - 安田益 雄・大岩紀生, 第 40 回燃焼シンポジゥム講演論文集, (2002), 61-62.

(9) Yamakita, R., Miura, K., Ishino, Y. and Ohiwa, N., JSME Int. J., 48-1, Ser. B (2005), 83-91.

(10) Yamakita, R., Ishino, Y. and Ohiwa, N., Proc. 1st Int. Symp. Micro and Nano Technol., (2004), CD-ROM : Paper No. XXXIV-C-04.

（11）加藤慎也 - 山北龍児 - 石野洋二郎 - 大岩紀生, 2004 年度 年次大会講演論文集, No. 04-1 (2004), 51-52.

(12) Yamakita, R., Ishino, Y. and Ohiwa, N., Proc. 6th KSME-JSME Thermal Fluids Eng. Conf., (2005), CDROM : Paper No. KD. 08.

（13）高分子大辞典, (1994), 1015, 丸善.

（14）石野洋二郎・山口譽起・大岩紀生，機論， 68-667, B (2002), 935-942.

（15）石野洋二郎・山口譽起 - 大岩紀生, 機論, $57-538, \quad B$ (1991), 206-212. 